\title{
Neofilia, criatividade e a despolitização do artista
}

Virginia Lais Souza

GIELEN, P.

Criatividade e outros

fundamentalismos.

São Paulo: Annablume, 128 p., 2015.

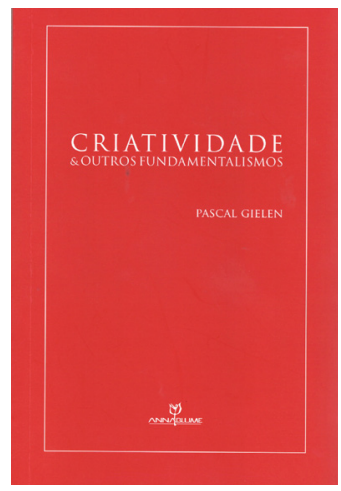

Resumo: Pascal Gielen discute aqui o atual momento em que tudo deve ser criativo. Convida-nos a refletir sobre as relações entre a criatividade e a indústria cultural. Segundo o autor, a sociedade neoliberal criou um certo fetiche do empreendedorismo individual, de que, muitas vezes, não nos damos conta.

Palavras-chave: criatividade; arte; autonomia; regime trabalhista.

Abstract: Neophilia, creativity and the depoliticization of the artist - Pascal Gielen discusses the current moment when everything must be creative. The neoliberal society have developed the fetish of the individual undertaking. Often, we don't realize the political and artistic implications of the agreement with this logic.

Palavras-chave: creativity; artist; autonomy; labour regime.

Professor de Sociologia da Arte e diretor do centro Arts in Society, na Groningen University, na Holanda, Pascal Gielen divide seu Creativity and other Fundamentalisms em dias e não em capítulos, como seria de se esperar. Em visível alusão à narração bíblica 
da criação do mundo, o autor organiza a discussão de seus assuntos em sete jornadas, reservando a oitava para sugerir ao leitor como lidar com o mundo da criatividade supostamente ininterrupta.

A frase que abre o volume já sintetiza a ideia principal: "A palavra mágica nestes dias é criatividade". Hoje temos que ser criativos e buscar soluções criativas. O problema, segundo Gielen, é que parece insuficiente ser criativo em um mundo tão horizontal ou plano (flat, na tradução inglesa). Toda criação surge de momentos de caos, então parece incompatível pensar criatividade em um mundo flat.

Leitor de autores como Slavoj Žižek, Peter Sloterdijk, Antonio Negri e Giorgio Agamben, Gielen refere-se ao contexto atual como a era da mediocridade. Segundo ele, vamos nos organizando a partir de táticas de sobrevivência e adaptabilidade. A ação predominante é a antecipação; pouco importa o que se faz ou os motivos que nos levam a fazer o que fazemos. O que rege nossa conduta é a capacidade de antecipar necessidades e ações - mantendo-nos sempre antenados com as tendências. Hoje todos fazemos pesquisas, todos somos criativos, impera no mundo midiático uma obsessiva criatividade.

O título do livro é sobre isso mesmo: o fundamentalismo da criatividade. O problema de ser criativo obsessivamente é que isso também gera uma desprofissionalização, uma vez que não sobra tempo, para quem tanto cria, para esse aprofundar verdadeiramente no que está fazendo. O mundo plano é incompatível com o tempo da investigação. A criatividade acaba suspensa por uma criação superficial, que é calculada em números. A qualidade fica reduzida à quantidade.

A lógica do mundo plano aparece nos mais diversos espaços. Gielen nota que, nas escolas de arte, isso já se tornou evidente: os alunos mudam rapidamente de área de conhecimento porque precisam ser polivalentes, tudo se reduz à interdisciplinaridade e à adaptabilidade. Não há chances para aqueles que desejam executar um ato ousado. O indivíduo passa a viver vislumbrando um futuro (próximo), porém desconsiderando o aprendizado e as suas habilidades (presentes). A proatividade nunca esteve tão em alta!

O pensamento neoliberal cria o que o autor chama de oportunismo. Os artistas estão mais preocupados com a visibilidade da obra do que com a obra em si. Um artista que busca verticalidade acaba sendo esmagado pelo mundo flat. O mundo flat é um mundo onde não há solidez; é um mundo líquido, como propõe Zygmunt Bauman. O objetivo é ver e ser visto; menos criação e mais exibição. O trabalhador valorizado hoje é nômade e geralmente associado a palavras como mobilidade, conexão, relação, comunicação, distribuição. Os artistas que trabalham em seus próprios estúdios são acusados de serem bairristas. Tanto artistas quanto curadores devem ser conectados e internacionais. Claro que essa conectividade é apenas superficial e tem índole instrumental: as relações surgem em razão de interesses, num dado e curto momento.

O capitalismo criativo diz que as pessoas deveriam ter o controle das condições de trabalho. Os curadores independentes, por exemplo, parecem melhores do que aqueles 
que estão em posições estáveis em museus. Podem ter maior capacidade de manobra, estão atentos aos outros curadores (seus concorrentes) e sabem lidar com a sucessão dos projetos que se multiplicam. Trabalham com contratos temporários ou sem contratos. A ideia de um trabalho para toda a vida é ultrapassada e demonstra a incapacidade do indivíduo de se adaptar. Há um culto pela neofilia. Nesse contexto, paradoxalmente, os projetos são efêmeros mas as pessoas lhes dedicam muito de seu tempo. Por serem trabalhos mal remunerados, os indivíduos estão sempre olhando para os próximos projetos e também têm o entendimento de um compromisso apenas parcial. Segundo o autor, o objetivo de tais projetos está fora dos mesmos: o objetivo é um novo projeto.

Pascal Gielen também discorre sobre a relação da mídia com a indústria cultural. Há aqui questões de direitos autorais já que, muitas vezes, a legislação não apoia a criatividade, mas sim as grandes indústrias. Parece que temos uma cultura possuída por alguém, a que não se pode aceder livremente. O consumidor pode ter a impressão de que escolhe, mas, na verdade, tudo é padronizado e em série. Os meios de comunicação não nutrem verdadeiro interesse pela arte e nos colocam diante de produções de baixa qualidade. Nesse caldo de cultura, fala-se muito sobre pessoas e a vida pessoal dos artistas acaba ganhando grandes proporções. A mídia desvia nosso olhar, cria sua própria expressão e coloca a crítica em risco. Dirige um monólogo para uma audiência, em geral, passiva. Temos assim uma homogeneização da cultura.

O autor ainda discute o que chama de banimento do trabalho. Não que pense que não exista trabalho: o que foi extinta é a organização em regimes trabalhistas. Estamos obrigados (e nos obrigando) a produzir o tempo todo, inclusive fora do horário que deveria ser destinado a tal tarefa. E somente quando pudermos sair dessa obediência diária, desse fetiche da criatividade, e quando denunciarmos a criatividade forçada, poderemos nos tornar verdadeiramente criativos. Para entrar neste terreno ainda desconhecido, precisamos de uma página em branco. E, como Gielen finaliza seu texto, precisamos aceitar o risco de uma busca no vazio.

Os assuntos abordados por Pascal Gielen certamente são de nosso interesse. Assim, saudemos a passagem do autor, em novembro de 2015, pela cidade de São Paulo, onde palestrou sobre Criatividade e outros Fundamentalismos, seu primeiro livro a ser traduzido entre nós, pela Editora Annablume.

Virginia Lais Souza é graduada em Comunicação das Artes do Corpo (PUC/SP) e Pedagogia (USP) e mestre e doutoranda em Comunicação e Semiótica (PUC/SP).

virginia_lais@yahoo.com.br 